\title{
Waste Management as a Practical Approach to Sustainable Development: A Case Study of the University of Benin,Faculty of Physical Sciences
}

\section{*11MASUEN, OI; OMOROGIEVA, OM}

\author{
Department of Geology \\ University of Benin, Benin City, Nigeria. \\ Email: isaacokpes@yahoo.com
}

\begin{abstract}
The wastes generated in the Faculty of Physical Sciences shopping complex and offices on daily basis for a period of one week continuous sampling have been determined. The summation of the wastes generated amounted to $355.38 \mathrm{~kg}$; the volume was arrived at following the daily scientific survey by gathering all wastes matrix generated in a particular day followed by manual sorting and weighing of the various fractions. Out of the total volume of the wastes generated, food wastes accounted for the total of $129.39 \mathrm{~kg} /$ week amounting to $37 \%$, paper and cardboard accounted for $105.73 \mathrm{~kg} /$ week taking $30 \%$ of the total. Plastic, glass and metals accounted for $92.91 \mathrm{~kg} /$ week, $15.93 \mathrm{~kg} /$ week, and $9.42 \mathrm{~kg} /$ week i.e. $(26 \%, 4 \%$ and $3 \%$ ) of the total waste matrix respectively. Correlation at $\mathrm{P}<0.5$ two tailed shows a positive correlation indicating that wastes generated were from a similar source, The results were presented in graphs. The ultimate results show that over 100\% of the wastes generated in the complex are recyclable and will increase the institution income and create employment opportunities if properly managed while in the same process enhance sustainable development. . ( JASEM
\end{abstract}

http://dx.doi.org/10.4314/jasem/v19i3.19

KEY WORDS: Waste, Generation, Recycle, Management and sustainable development

\section{Introduction}

Solid waste is any solid material that is being thrown away because it is useless. The term refuse is synonymously used with the term solid waste (Manahan, 2000; Abdul-Jalil, 2010).

Waste management is one of the important services provided by most urban authorities. Solid waste need to be characterized by sources, generation rate, types of waste generated and composition in order to monitor and control prevailing waste management systems while improving on the existing system (Nathason, 2004). Solid waste generation and management is a complex system that requires the cooperation of all and sundry (Lober, 1996; Omuta 1999), this is because the end product of waste be it solid, bio solid, hazardous, infectious etc. can lead to disease epidemic hence the need for a wholistic approach for effective management (Chandrappa and Das; 2012; Achudume, and Olawale, 2009; Erick, 2003)

Municipal Solid Waste (MSW) includes waste produced from commercial, domestic, industrial, demolition and institutional services. It is imperative to state that the data pertaining to municipal solid waste vary greatly among the waste studies. Usually, waste management decisions are based on household waste which constitutes a small portion of the total waste stream (Chandrappa and Das; 2012; Nathason, 2004). Generally, solid waste is divided into two main categories; rubbish and garbage.

Rubbish are those part of refuse that are not putrescible(non-biodegradable), they could be combustible or noncombustible. Typically combustible rubbish consists of materials such as paper, cardboard, plastics, textile materials, wood etc. The non-putrescible include such wastes as glass, tin cans, ferrous materials etc.

Garbage on the other hand includes putrescible (biodegradable) aspect of solid waste such as food waste. They are noncombustible and they are the part of refuse that can be converted to organic manure through composting and they are recyclable, (Manahan, 2000; Nathason, 2004; Chandrappa and Das; 2012). Until 1950, solid waste disposal had not posed any problem on the environment; the period of 1953 - 1955, the spread of viral diseases to hogs 
attracted the attention of several sanitary engineers and farmers. Today, waste is one of the major problems posing threat to the environment and public health.

The significance of this present research is to characterize the wastes generated from faculty of physical sciences and the shopping complex in an institutional setting; the University of Benin, South South geopolitical zone of Nigeria and strategize effective management system in order to maximize profit, create employment, and enhance sustainable development.

\section{MATERIALS AND METHODS}

The University of Benin is a tertiary institution located in Benin City the capital territory of Edo State, South-South Geopolitical zone of Nigeria. University of Benin consists of two campuses (Ugbowo and Ekewan) with fourteen (14) faculties, three (3) institutes, one (1) College and ten (10) Centers. The Shopping complex under study is located in the Faculty of Physical Sciences, Ugbowo Campus of the institution. There are five (5) Departments in the faculty which include ; Chemistry, Computer Science, Mathematics, Geology and Physics; (Data generated from University Admission Board), the faculty also houses the Department of Optometry in the Department of Physics. The study area is located on latitude $06^{\circ} 48^{\prime}$ 47.9" $\mathrm{N}$ and longitude $005^{\circ} 48^{\prime} 47.6^{\prime \prime} \mathrm{E}$ within the Ugbowo Campus of the institution. The shopping complex consist of forty four (44) offices/stores, the breakdown is as follows; ten (10) snacks shops, twenty three (23) photocopy shops, one each of cyber café , paper binding, cosmetic, and financial institution, three (3) book shops/accessories and four (4) restaurant. Figure (1) below is the location map of the study area with sample collection point.

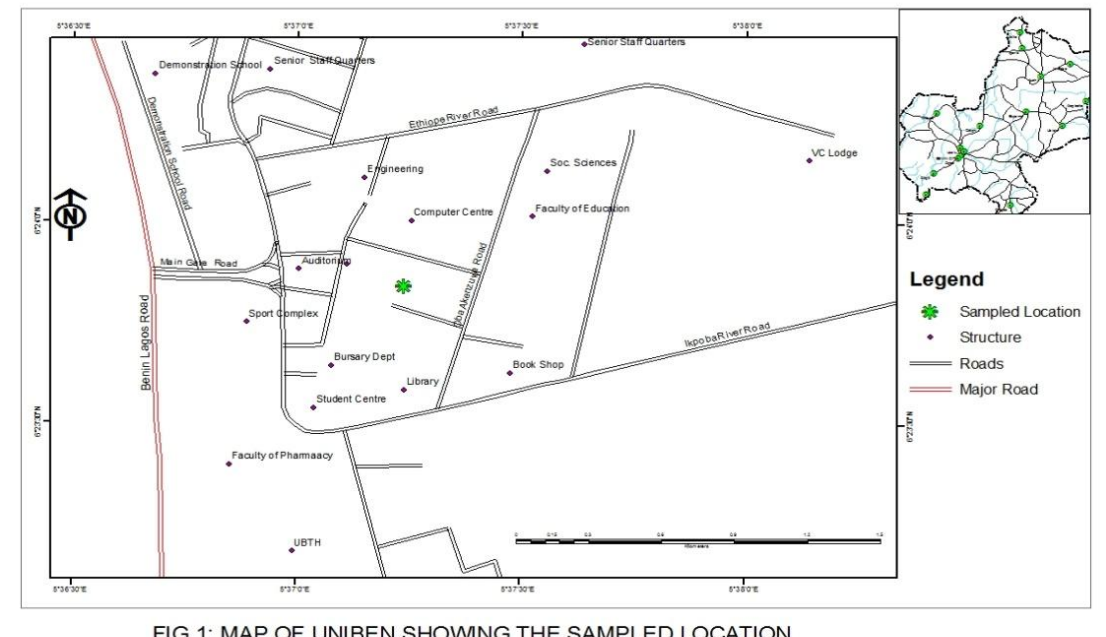

The climate in the area falls within the tropical climate characterized by two distinct conditions of wet and dry seasons. April-October is wet with a brief fall in August generally referred to as August break. The dry season lasts from November to March. Temperatures across the state is relatively high with a very narrow variation in seasonal and diurnal ranges $22-36^{\circ} \mathrm{C}$, the annual mean temperature and rainfall are $23.47^{\circ} \mathrm{C}$ and $217.80 \mathrm{~mm}$ respectively. Three vegetation belts are discernible from the south to the northern of the country, the mangrove swamp forest in the southern part, the rain forest at the middle while the northern part has the savannah vegetation (Edo State, 2013).

\section{METHODOLOGY}

A field Scientific survey was used in this research work. The survey was carried out for six (6) days, Monday, $19^{\text {th }}$ to Saturday, $24^{\text {th }}$ of May 2014 between the hours of $6 \mathrm{am}$ and 10am. The wastes generated from the shopping complex on a daily basis for the previous day were gathered before the commencement of business on the new day. Wastes were manually sorted to their respective fractions and weighed using a scale in order to determine the quantities of various wastes generated and the summation of all the wastes generated for a particular day. The waste fractions include plastic polymer, cardboard/paper, metal, food and glass shown in plates 1-8 below. 


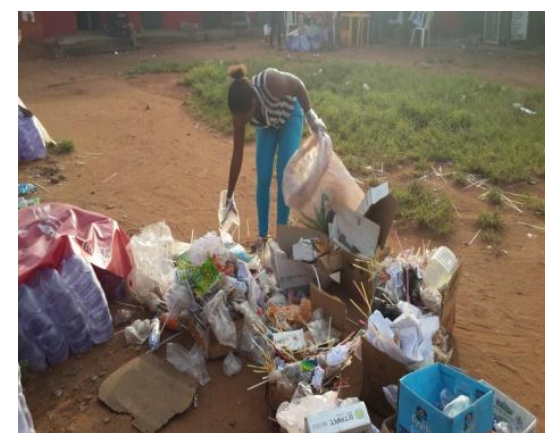

Plate 1: Waste Gathering

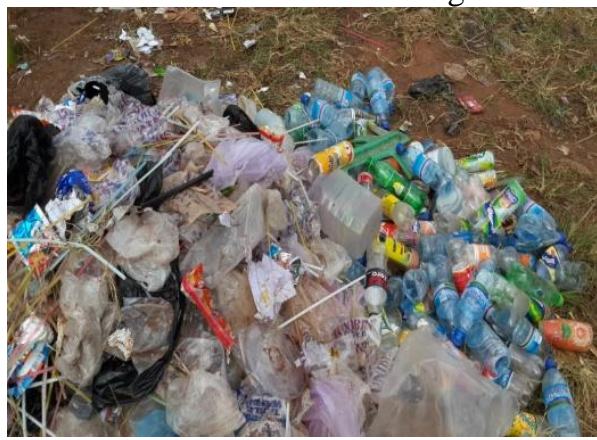

Plate 3: Plastics and Polythene Waste

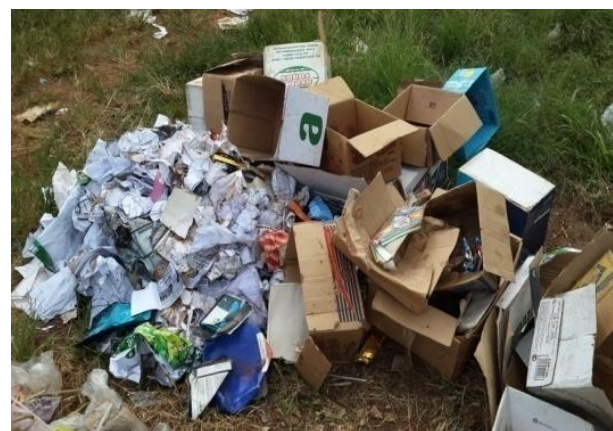

Plate 2: Paper and Cardboard Waste

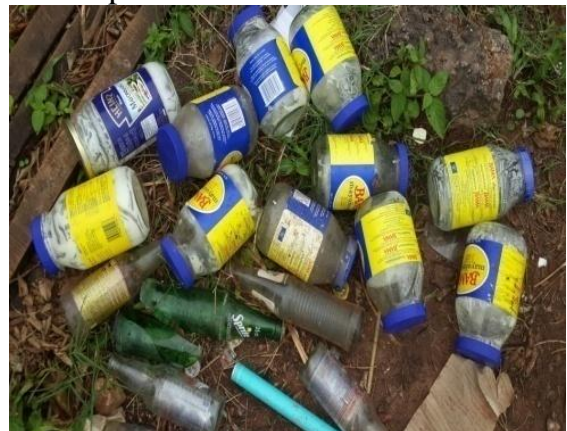

Plate 4: Glass Waste

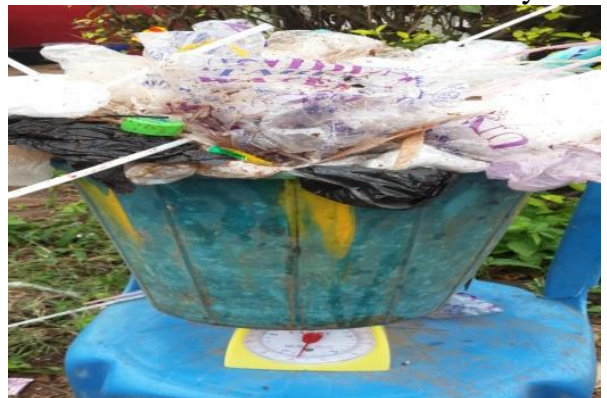

Plate 5: Weighing of Waste

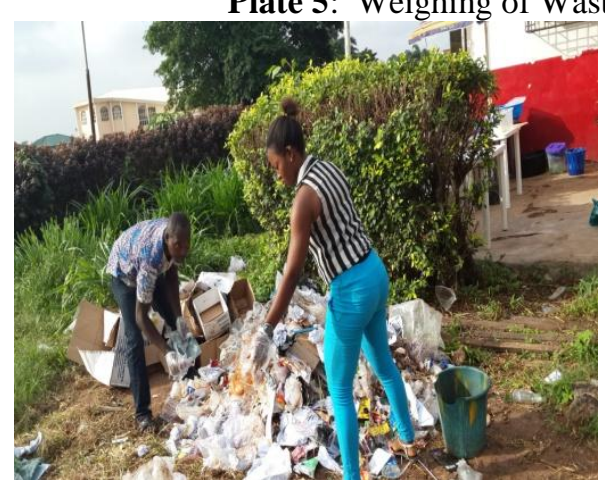

Plate 7: Manual Sorting of Waste

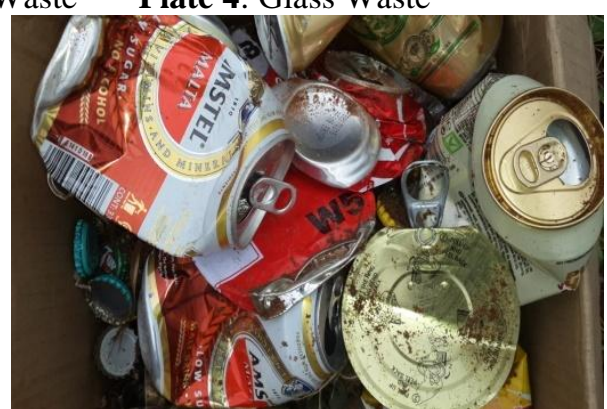

Plate 6: Metal Scraps

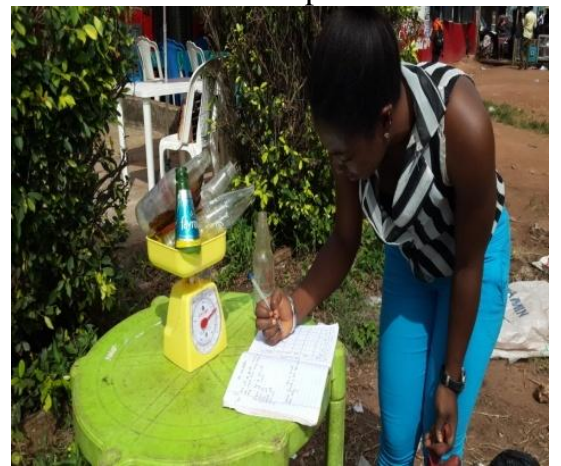

Plate 8: Data Recording

Plate 1-8 photos are credited to the authors

There are forty four (44) shops/offices in the complex in addition to the various offices present across the departments in the faculty. The results obtained from the survey were used to compute the percentage waste generated from each of the shops.

\section{RESULTS AND DISCUSSION}

The results emanating from this research is graphically presented and discussed below.

The total amount of waste generated over the one week of continuous survey was 353.38 kilogram (Fig. 3 ), with food waste contributing $129.39 \mathrm{~kg}$; paper waste amounted to 105.73 kilogram. The total amount of plastic waste generated was 92.91 kilogram while that of glass was 15.93 kilogram, metal scraps recorded 9.42 kilogram. The percentage 
waste contribution from shop type was also calculated in (Fig. 4). Mathematically, the figures were arrived at by using the number of shop types to divide the total number of shops and then multiply by the total waste generated. On the other hand, the percentage contribution of each waste matrix was calculated by using the amount of waste generated in shop types to divide the total waste generated in the entire complex and multiply by one hundred that is $\mathrm{N} / 44 * 353.38$ while $\mathrm{X} / 353.38 * 100$ where $\mathrm{N}$ is the number of shop types and $\mathrm{X}$ is waste matrix generated for each waste type.

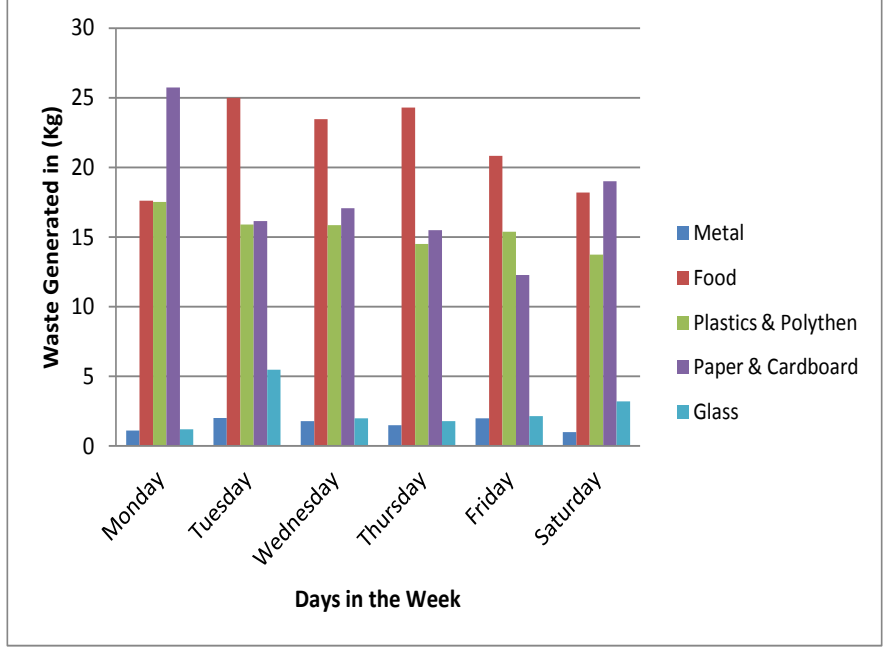

Fig. 2: waste generated each day of the week $(\mathrm{mg} / \mathrm{kg})$

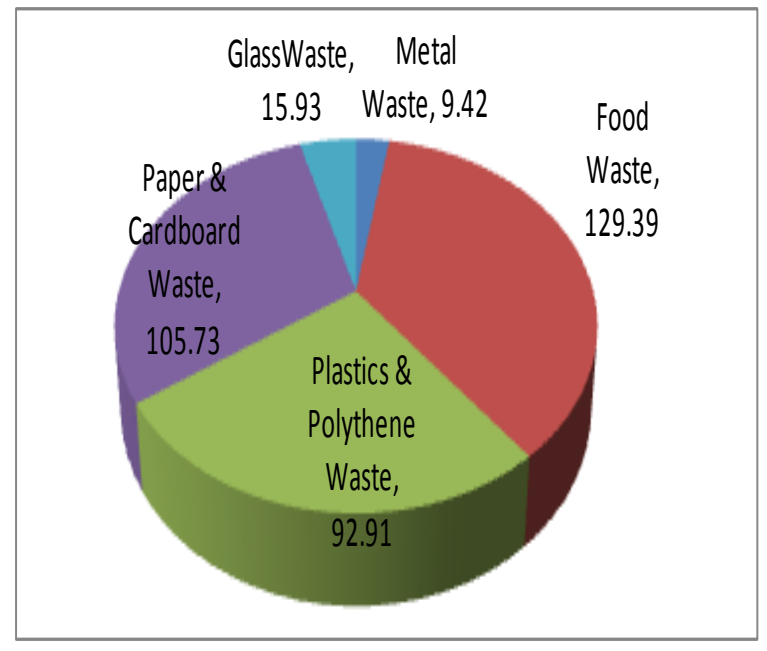

Fig. 3: total waste contribution in

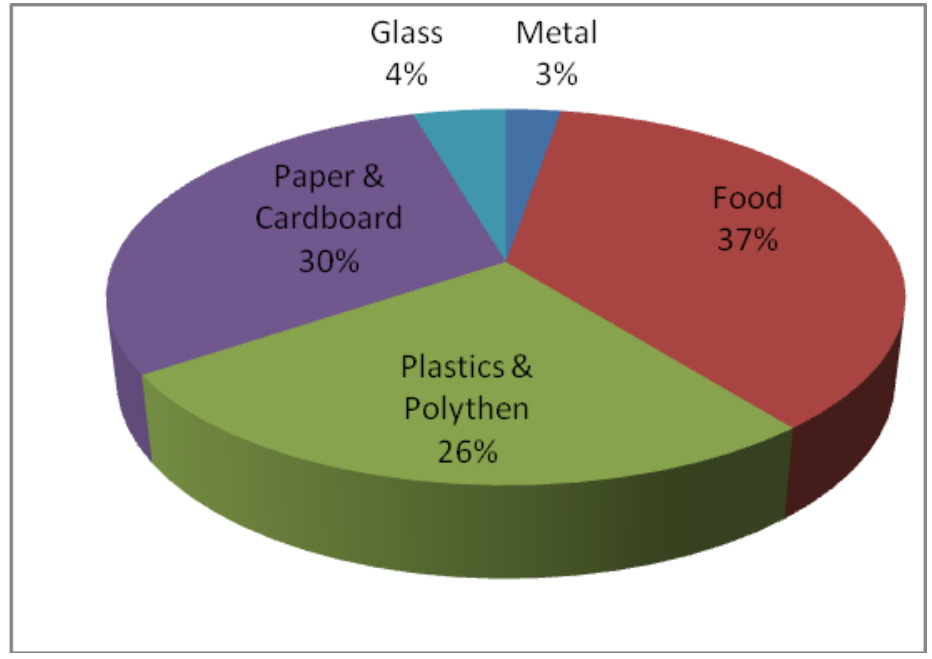

Fig. 4: percentage waste matrix contribution

Table 1: Sources of waste

\begin{tabular}{lllll}
\hline S/N & Sources of Waste & Numbers Available & A & B \\
\hline $\mathbf{1}$ & Snacks & 10 & 80.31 & 22.73 \\
$\mathbf{2}$ & Photocopying shops and offices & 23, excluding departmental offices & 184.7 & 52.27 \\
$\mathbf{3}$ & Cyber café & 1 & 80.31 & 22.72 \\
$\mathbf{4}$ & Book binding & 1 & 8.03 & 2.27 \\
$\mathbf{5}$ & Cosmetics & 1 & 8.03 & 2.27 \\
$\mathbf{6}$ & Book shop and accessories & 3 & 24.1 & 6.82 \\
$\mathbf{7}$ & Restaurant & 4 & 32.13 & 9.1 \\
$\mathbf{8}$ & Financial home & 1 & 8.03 & 2.27 \\
Total & & 44 & 353.4 & 100 \\
\hline
\end{tabular}

Where $\mathrm{A}=\mathrm{N} / 44 * 353.38$ and $\mathrm{B}=\mathrm{X} / 353.38 * 100$ 
Paper waste accounted for $105.73 \mathrm{~kg}$ of the total waste matrix generated in the study area, (Fig. 3) while the daily average was $17.62 \mathrm{~kg}$ (Fig. 2). The sources of the paper/ cardboard include other shops in the complex and the various offices in the faculty besides restaurants, cosmetic and snacks shops (Table 1). Previous work suggests that papers are not putrescible but combustible (Montgomery, 2003).

In the process of combustion which is a routine waste management practice particularly in developing countries such as Nigeria, $\mathrm{CO}_{2}, \mathrm{NO}_{4}, \mathrm{SO}_{4}$, and $\mathrm{CH}_{4}$ are released into the atmosphere. These gases and a host of others can cause ozone layer depletion, acid rain and can also reduce visibility (Manaham, 2000).

Plastic/polythene wastes are non biodegradable, however, combustible; the consequence on the environment is similar to those of paper waste. In the area of study, it was found that plastics/ polythene waste contributed $92.91 \mathrm{~kg}$ out of a total waste matrix of $353.38 \mathrm{~kg}$ (Fig. 3). The daily average record was $15.49 \mathrm{~kg}$ during the period of survey (Fig. 2) as represented by the lemon green colour. The percentage contribution of plastics/polythene waste to the total waste matrix was found to be $26.29 \%$ (Fig. 4). The forty four (44) shops and the various offices in the faculty contributed to the plastic waste generated in one way or the other. The plastic/polythene wastes include polythene bags, water sachets, straws, plastic bottles and other plastic materials as represented in plate (3) above. Glass waste was not much as the total figure contributed to the total waste matrix during the one week scientific survey was only $15.93 \mathrm{~kg}$. Glass waste is not in any way environmentally friendly because it is neither combustible nor putrescible. It can pose adverse health risk and reduce land for agriculture if not properly disposed. The daily average and percentage contribution of glass waste to the entire waste stream are $2.66 \mathrm{~kg}$ and $4.51 \%$ respectively and it is represented with the sky blue colour in the histogram (Fig. 3,4 \& 2) respectively.

Just like glass waste, metal wastes are non biodegradable, they are also not combustible. The result for metal waste in the study area accounted for $9.42 \mathrm{~kg}$ (Fig. 3) with a percentage contribution of $2.67 \%$ (Fig. 4), the daily average resulted in $1.57 \mathrm{~kg}$ (Fig. 2). Metal wastes can increase the concentration of elements above their background value thereby causing anomaly in the natural concentration of such elements in plants and animal through food chain. These metals are absorbed by plants, they bioaccumulate either in the stems, leaves or fruits. On the other hand, they can be washed by surface processes such as runoff, storm water and erosion into the water system, consequently when consumed by living organisms such as man they can cause various diseases.

Management System and Estimated Profit: Waste management is one of the important services provided by most urban authorities. Solid wastes need to be characterized by sources, generation rate, types of wastes generated and composition, in order to monitor and control prevailing waste management systems while improving on the existing system (CalRecoverys, 1982; Nathason, 2004; Nath,1993; NERI, 1996); consequently, University of Benin authorities have no choice than to follow suit. The research revealed that the wastes generated within the institution using the Faculty of Physical Sciences as a case study could be managed properly by applying the three " $R$ " $\left(R^{3}\right)$ method which stands for reuse, reduce and recycle. Over $90 \%$ of the waste stream generated in University of Benin can be recycled and reused. Separating, recovering, and reusing components of solid wastes that may still have economic value is called recycling. Composting can also be considered a recycling process, since it reclaims the organic parts of solid waste for reuse as mulch or soil conditioner (Chandrappa and Das, 2012). Yet other waste materials have potentials for reuse. These include paper, metal, glass, plastic, and rubber. Recovered broken glasses can be crushed and used in asphalt pavement while in some cases; it can be used for security on fence at homes in lieu of barbed wire. Colour-sorted glass can be crushed and sold to glass manufacturers like Coca Cola and Seven up bottling company as cullet, an essential ingredient in glassmaking. Metal scraps can be baled as scrap or compacted for reuse by smelters.

In the paper/cardboard stream which consists of photocopy papers, old newspapers; these could be sorted by hand in order to remove corrugated materials and mixed papers. They can be baled or loose-loaded and sent to the paper mills like the Watchtower Paper Mill at Igieduma, where they are reused in the making of magazines and various Christian literatures. Mixed paper can be separated from corrugated paper for sale to tissue mills. Rubber is sometimes reclaimed from solid waste and shredded, reformed, and remolded in a process called revulcanization, but it is usually not as strong as the original material. Shredded rubber can be used as an additive in asphalt pavements, and discarded tires may be employed as swings and other recreational structures for use by children in "tire playgrounds" like the University Staff School. The straws can be re-designed and used as window and door curtains in 
beer parlour and hair stylist shops. Another method of treating solid waste is composting, a biological process in which the organic portion of refuse is allowed to decompose under carefully controlled conditions. Microbes metabolize the organic waste material and reduce its volume by as much as 50 percent (Chandrappa and Das, 2012). The stabilized product is called compost or humus. It resembles potting soil in texture and odour; and may be used as a soil conditioner or mulch for crop production.

Composting offers a method of processing and recycling both garbage and sewage sludge in one operation. The University of Benin, being a vast institution with a large farm managed by the Faculty of Agriculture can judiciously utilize the food waste and allied products through the process of composting as organic manure in the farms. This will, no doubt, reduce the cost of fertilize procurement, maximize the institutional internally generated revenue (IGR) and preserve the soil from heavy metal and other inorganic contaminants for sustainable development. According to United Arab Emirate, Ministry of Environment (1999, 2000), about 1.8 million tones of solid waste are being recycled in the last few years. The institutional solid waste augmented from 94,000 tons to 292,000 tons between 1980 and 1987 followed by a decline to about 6,000 tons in 1999 due to waste recycling (Renbi, 2002). Since waste production is a function of land use as well as its composition which is inversely proportional to the possible soil damage and bacterial contamination of the environment (Achudume and Olawale 2009; Lober 1996; Omuta 1999). The authority of the University of Benin is challenged to rise up to her expectation to provide at least three waste baskets of various sizes depending on the type of waste generated in all of the offices in the institution as well as on the streets of the institution while emphasizing that all her tenants in various shopping complexes and other strategic positions alike should do the same. This will help to reduce the time spent in manual sorting in the process of separation of waste matrix.

The study area above, the institution is made up of fourteen faculties, three institute, one college and ten centers. Assuming that each faculty, center, college and institute have at least one shopping complex of the same size with that of the case study shopping complex; there will be twenty seven shopping complexes in the institution. If the wastes are generated at the same rate with the same volume recorded for the case study, then the following will be obtainable;
Metals Scraps $=9.42 * 27 * 52=13225.68 \mathrm{~kg}$

Food $=129.39 * 27 * 52=181663.56 \mathrm{~kg}$

Plastic and Polythene $=92.91 * 27 * 52=130445.64 \mathrm{~kg}$

Paper and Cardboard $=105.73 * 27 * 52=148444.92$

$\mathrm{kg}$ Ground Total $=496145.53 \mathrm{~kg}$

From the figure above, an estimate of $496145.53 \mathrm{~kg}$ wastes equivalent of 496.15 ton will be generated annually. The study revealed that the total waste matrix from the institution under study is $100 \%$ recyclable, reduce and reuse; for example the food can be converted to organic manure as soil conditioner, plastic bottles can be reused in the institution water factory, empty water sachet can be used to grow seedlings in the institution's farm, metal scraps can be sold out to companies that make use of them for the production of kitchen utensils and other allied products at the rate of fifty (\# 50) naira per kilogram though not official price but general price from survey findings while the glass waste can be crushed and reused, it can also serve as security gadget in lieu of barbed wire on fence.

Conclusion: The correlation coefficient range of $(\mathrm{R}=$ $0.94-1$ ) at $\mathrm{P}<0.05$ two tailed (Fig. 5) below show that the waste generated were from similar source. The study revealed that $100 \%$ of the wastes generated can be properly managed for maximum benefit thereby enhancing job creation, promote good environment, and enhanced sustainable development which is the core interest of the society. Therefore, the authority of University of Benin as a matter of urgent priority employ professional staff to manage her wastes in order to actualize the target oriented.

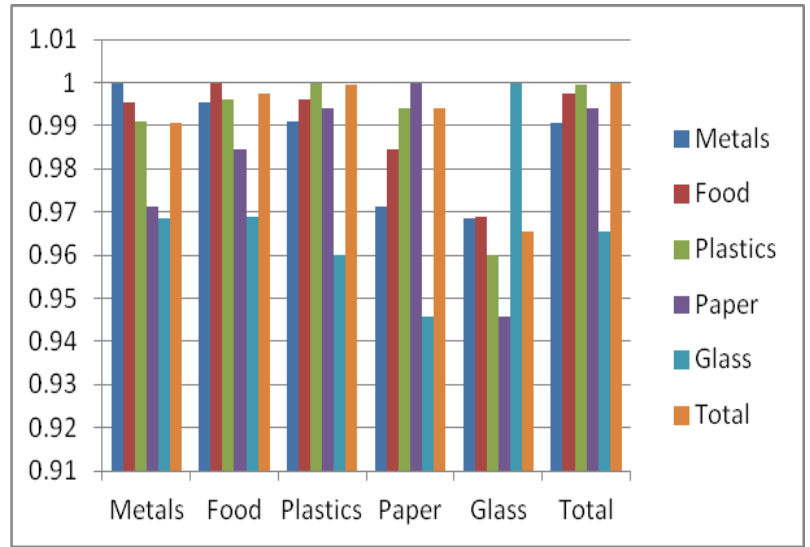

\section{REFERENCES}

Abdul-Jalil, M.D (2010): Sustainable Development in Malaysia: A Case Study of Household Waste Management. J. Sustain Dev 3(3): 91-102

Glass $=15.93 * 27 * 52=22365.72 \mathrm{~kg}$ 
Achudume, A.C and Olawale J.T (2009): Occurrence of Antibiotic Resistance Bacteria in Waste Site of Ede South West Nigeria. J.Environ Biol

CalRecovery Systems, Inc (1982): Noorconsult A.S and Engineering-Services, Metro Manlina Solid Waste Management Study-Review of Existing Conditions

Chandrappa, R. and Das, D.B (2012): Solid Waste Management. Environmental Science and Engineering, DOI: 10.1007/978-3-642-286810_2, Spriger-Verlag Berling Heidelberg

Edo State Government (2013): The Edo State Statistical Year Book.

Fourth edition produced by the State Central Office of Research and Statistics Pp131

Erick, A.(2003): Globalization, Urbanization and Municipal Solid Waste Management in Africa, African Studies Association of Australasia and the Pacific, Conference Proceedings-African on a Global Stage

Lober, D.J (1996): Municipal Solid Waste Policy and Public Participation Household Sources Reduction. J. Inter Solid Waste Ass 14:29-35

Manaham (2000): Environmental Chemistry, $\left(7^{\text {th }}\right.$ edn.).CRC Press,Boca Raton, USA, ppl10-112
Ministry of Environment (1999): Annual Report, Ministry of Environment, Singapore

Ministry of Environment (2000): Annual Report, Ministry of Environment, Singapore

Montgomery, C.W (2003): Environmental Geology. Sixth Edition, McGraw-Hill Higher Education Pp554

Nath, K.J (1993): "Solid Waste Managemen in the Present India Perspective', Proceedings of ISWA Annual Conference, Jonkoping, Sweden

Nathason, J.A (2004): Solid Waste Management. Encyclopedia Britanica; view online $3^{\text {rd }}$ Aug, 2014 and last updated $4^{\text {th }}$ April, 2014.

National Environmental Engineering Research Institute (1996): Background Material for Manual on Solid Waste Management

Omuta, G.E.D; (1999): Towards a Sustainable Environmental Culture in Nigeria, Daily Sketch Nigeria, March 25, No 11659

Renbi, B; and Mardina, S (2002): The Practice and Challenges of Solid Waste Management in Singapore. Waste Manage 22: 557-567 